\title{
An Investigation of Tourism Potential, Communities' Awareness and Engagement Towards Community Based Ecotourism Development in Kehitastse Forest and Environs, Ethiopia
}

\author{
Ayana Fiseha \\ Lecturer at Bahir Dar University College of Business and Economics, Department of Tourism and Hotel \\ Management, Bahir Dar, Ethiopia
}

\begin{abstract}
The research focuses on investigation of tourism potential, communities' awareness and engagement towards community based ecotourism development in kehitastse forest and environs. Descriptive research design was employed and 91 samples selected out of 957 households through simple random sampling technique for quantitative data; however purposive sampling technique was used for qualitative data. The data were collected through questionnaire survey, key informant interview, field observation and secondary data sources. Over all thematic data analysis method was used. Data collected through questionnaire was analyzed through using Univariate descriptive statistics (range, frequency and percentage) while qualitative data was mainly used to triangulate the study to reach in to conclusion. The finding shows that the area is rich in natural and cultural tourism resources for community based ecotourism development. Moreover, the community's positive attitude and engagement towards tourism developed in the area are some of prospects for community based ecotourism development although unsustainable exploitation of the forest for grazing, fire wood, housing, charcoal, lumbering household and agricultural materials are some of adverse effects on sustainable development of the forest. It is recommended that environmentally sound, culturally friendly and economically feasible communitybased ecotourism should be developed in the destination to bring local sustainable development.
\end{abstract}

Keywords: Tourism Potential, Community Based Ecotourism Development, Sustainable Development, Communities Awareness and Engagement

DOI: $10.7176 / \mathrm{JTHS} / 42-02$

Publication date:July $31^{\text {st }} 2019$

\section{Introduction}

The tourism industry is one of the fastest growing industries in the world (Rodger, 2005). It contributed US\$7.6 trillion to the global economy ( $10.2 \%$ of global GDP) and generated 292 million jobs ( 1 in 10 jobs on the planet) in 2016. For the sixth consecutive year, industry growth outperforms that of the global economy (World Travel \& Tourism Council, 2017). Arrivals reached 1.2 billion in 2016, 46 million more than in 2015 (UNWTO, 2017). With a forecasted 1.8 billion international tourists by 2030 , the industry has the potential to play a key role in creating high-quality employment opportunities, act as a vehicle to protect and restore our planet's biodiversity and help build bridges between people and cultures (World Travel \& Tourism Council, 2016).

The industry is giving larger focus on environmental sustainability (IATA, 2016). Resource efficiency, environmental protection and climate change is central to the industry's agenda. Stainability has accelerated as a policy issue in the past decade as the planet remains under threat of existential climate change (WEF, 2017).

The increasing flow of tourists to destination from time to time has resulted in mass tourism (Murphy (1985, p 22) which has led to a range of problems such as environmental, social and cultural degradation, unequal distribution of financial benefits, the promotion of paternalistic attitudes, and spread of diseases (Hong, 1985). Some of these problems have become global concern since environmental awareness increased. As a result, many scholars have agreed that mass tourism in the 21 st century is becoming unsustainable. This concern initiated the concept of ecotourism which is popular in many developing countries at recent years (Kelly, 2009). It is new forms of tourism emerged in the late 1980s (Koeman, 1998). It is nature-based tourism which minimizes the negative environmental, economic and social impacts often associated with mass tourism; maximizes environmental conservation; and improves the livelihoods of local people (Cater and Lowman 1994).

It meets the needs of present tourists and host regions while protecting and enhancing opportunities for the future (WTO, 2001). WWF is taking action to reduce negative impacts, and to encourage responsible tourism that enhances not only the quality of life, but also natural and cultural resources in destinations (Denman, 2001). UNESCO sent a mission to Ethiopia when Ethiopia applied to UNESCO for development of wildlife conservation in 1963. This mission observed that wildlife conservation was contained as part of a wildlife hunting regulation which was under the Ministry of Agriculture (Tesfaye, 1996). The mission recommended the creation of an organ to carry out wildlife conservation and some areas of high conservation priority to be developed into national parks. From 1966 onwards national parks have been gradually expanded in Ethiopia. Currently there are 25 national parks; there are also other protected areas such as wildlife sanctuaries, game 
reserves, controlled hunting areas and community conservation areas (Adem, 2008).

The Protected areas of Ethiopia cover about 14\% total area of the country (SDPASE, 2008) which are rich in valuable natural resource medicinal plants, endemic plants and animals, amazing variety landscapes, Afroalpine highlands soaring to around 4,300 meters above sea level, deserts sprinkled with salt flats and yellow sulphure, lake lands with rare and beautiful birds, massive mountain chains, majesty Great Rift valley, whitewater rivers, savannah which is rich with games, enormous waterfalls, dense and green jungle forests are some of landscape beauties to develop tourism industry (Viva Ethiopia Tour, 2014). In addition to abundant natural resources, Ethiopia has cultural tourist attractions for ecotourism development: world heritages, archaeological and historical resources, diversified culture, colorful ethnic groups, historical churches and monasteries, local arts and artifacts are some to mention (Ethiopian Tourism Commission, 1995).

Ethiopia has diverse potential tourism attractions to earn more than 20 billion birr annually from ecotourism. However, stands among the lowest tourism beneficiaries in Africa. It earns only 60 million birr annually from ecotourism (EWCA, 2015). In Ethiopia there is an opportunity to develop different types of tourism activities at protected and surrounding areas such as wild life tourism; bird watching tourism, controlled hunting tourism, hiking, trekking, mountain climbing, rock climbing, rural tourism, geo tourism, safari tour, site seeing tourism (Henze, 2007). On the other hand, most of protected areas of Ethiopia are still exposed to severe degradation due to failure of creating alternative options like community based ecotourism (Adem, 2008) for example Kehitastse forest is not investigated whether it is suitable for tourism development particularly CBET development. Therefore, this research is aimed to investigate community based ecotourism development with specific objectives of: tourism potential, communities' awareness and engagement towards community based ecotourism development and challenges.

\section{Article Review}

Across the globe, people express concern about social injustices and environmental problems. They are increasingly aware of the need for low impact tourism which does not harm the environment. They tend to want to support local conservation or community development initiatives. They are themselves moving from consumptive to less consumptive activities, often adopting "green consumer" life styles (IUCN, 2002). Community based ecotourism (CBET) is the best concern for this issue. It is sustainable tourism, which is based on ecological principle and sustainable development theory. Its main aim is to conserve resources, especially biological diversity, and maintain sustainable use of resources. It provides ecological experience to travelers, conserve the ecological environment and enhance economic benefits to local community (Hongshu and Mintong, 2009). It is alternative form of ecotourism where local communities have extensive involvement in every aspect of tourism such as ownership, management and benefit sharing. Major proportions of the benefits remain within the community (Denman, 2001). It has emerged as one of the most promising methods of integrating natural and cultural resource conservation in to local income diversification in the developing world (Miller, 2004). The ownership and control of cultural and natural resources can sustain traditional practices and the expression of their cultures in authentic ways despite innovations or changes since they are the qualified innovators who can make changes in ecotourism sites, objects, images and even in how people reflect on past events and their previous ways of life (Sofield H.B.T. (2003) and Cole, (2006)). As a result, it creates sense of ownership and empowerment in the community (Denman, 2001). In this approach of ecotourism development, communities manage and maintain ecotourism sites, infrastructure, makes voice and decisions on ecotourism planning and implementation utilizes resources to generate income through operating ecotourism activities and uses the operating profits to enhance the lives of community members (Sproule, 1996). Local voices, values and knowledge are proactively channeled into strategies for managing resources and major proportion of the benefit remains within the community (Denman, 2001).

The potential benefits of CBET are considered mainly from environmental and economic perspective which is notion of local sustainable development (Weaver and Lawton, 2007). It is best tool and part of the strategic response to integrate conservation and development projects for challenges of environmental, socio-cultural and economic sustainability especially in developing countries (Duffy, 2006). ). Its demand is that it provides economic benefits to local people while simultaneously conserving natural resource through low- impact, nonconsumptive use (Kelley, 2009. Because of its emphasis on local communities, most of the literature explores the socio-cultural implications of CBET (Weaver and Lawton, 2007) i.e. it is important to remember that ecotourism is a business in which community-led initiatives, Private enterprise and investment should be encouraged with effective structure which enables the community to influence, manage and benefit from ecotourism development and practice. The degree of community involvement and benefit can be developed over time (Stonich, 2000).

Ecotourism and protected areas have strong connection. In recent years, the relationship between natural resources and ecotourism, people and economics have received high attention from academics, as well as both government and non-government conservation and development agencies in many nations. Varieties of socioeconomic reasons are responsible for this concentration (Creswell and Ma Laren, 2000). Due to increase in 
environmental destruction, ecosystem degradation, habitat disappearance and biodiversity decline, most nations have made efforts to protect some portion of their remaining natural resources; but difficulty for governments to manage and rationalize scarce resources, and allocation of large areas of land and water for protection is highly increasing. The major constraint for the government to solve these problems is financial issues and sense of ownership of community to protected areas (Woodley, 1999). There might be a potential threat, and an opportunity for conservation of natural resources. Many of the threats of protected areas arise from the needs of local populations to use resources to survive (Norris, 1992). In fact, it is now recognized that communities and protected areas cannot co-exist in the absence of local support for the conservation objectives of the protected area (McNeely, 1992 and Strasdas, 2002). These considerations are particularly observed in developing countries. The result has been that ecotourism has come to be widely viewed as a positive means of improving people's standard of living (UNWTO, 1997). Over all, revenue generated through tourism is both an important incentive and a source of funding to protect the natural environment (WEF, 2017)

\section{Description of the Study Area}

The kehitaste forest is one of largest Natural dense state protected forests found at Awi zone, Amhara National Regional State of Ethiopia. According to M. Mekonnen, M. Gebeyehu T. Sewunet, M. Gebeyehu, B. Azene and M. Melesse (2016) Natural dense forest is a type of forest cover in which the forest comprises of diverse tree and shrub species with full canopy cover (greater than $80 \%$ canopy cover). Tree height of the dense forest is from 5 to $12 \mathrm{~m}$ and higher. Such forest types are observed in the priority and protected state forests, parks, churches, and the riparian forests with high and rich species composition.

The geographical position of Kahitestse forest is $10^{\circ} 57^{\prime} \mathrm{N}$ and $36^{\circ} 56^{\prime} \mathrm{E}$ with total land area of 5266.35 hector. The forest is located between three woredas and $17 \mathrm{Km}$ towards west direction from Injibara town (capital city of Awi zone) which is found at highway of historical route of Ethiopia 456 kilometers north of Addis Ababa. It is located at proximate area to Northern Historical Tourist Route of Ethiopia from Addis Ababa via Injibara to Bahir Dar city, Monasteries of Lake Tana, Historical city of Gondar, Simien Mountains National Park, Lalibala Rock Hewn Churches, and historical city of Axum with great opportunity to be visited. On the other hand, the forest is located $5 \mathrm{~km}$ away from asphalt road of Injibar to Ethiopian Great renaissance water reservoir of Abay at Binishangul- Gumuz region via Chagni town.

Topography of the area ranges from 1900- 2800 meters above sea level with plain, plateau, hills and valley land features. Regardless of diverse topographic features, the forest is characterized by moderate $\left(18^{\circ} \mathrm{c}\right.$ average) temperature. Regarding to rain fall the area gains the rain mainly from mid of May to end of September. The average annual rain fall is $2000 \mathrm{~mm}$. Although there is high rain fall during July to August, the forest is not affected by erosion since it is covered with dense flora. Crop production is the main socio economic activity of local communities during rainy season although there is increasing utilization of water for irrigation during dry season to maximize the total production. Cattle, sheep, goat, horse, ass, mule and poultry husbandry are also sources of income to communities (BOFED, 2012).

\section{Research Methodology and Materials}

To realize the study, the data were collected through questionnaire survey from 91 household of local communities that covered background of the respondents, tourism potential, communities' awareness and engagement towards community based ecotourism development. Both close-ended and open-ended questions were employed. In depth expert interview from 20 key informants of forest security, culture and tourism bureau officers, and natural resources office representatives of the zone were used as subjects of the study. Field observation through structured checklist to observe potential tourism resources and challenges to the forest, Information was also collected and recorded through Photographs. Secondary data source relevant to the topic under study were reviewed and used for analysis.

The process data analysis and drawing of conclusion was based on empirical evidence. Data collected through questionnaire was analyzed through using frequency and percentage. Qualitative data obtained using key informant interviews, field observation and secondary data sources were analyzed through qualitative data analysis method. It was contextualized and themed in to similar characteristics and mainly used to triangulate the study to reach in to conclusion. Tables, Pictures and textual description, were used as required to present the results of the study.

\section{Results and Discussion \\ 4.1 Potential Tourism Resources}

Kehitaste forest and environs is endowed with different natural and cultural tourism resources.

\subsubsection{Natural Tourism Resources}

The forest is wealthy in different fauna and flora species, landscape and water bodies. Moreover, it has moderate climate which is suitable for inhabitants of flora and fauna biodiversity. These in turn make high potential for 
CBET development which is current issue that drives attention of the world to alleviate poverty and global warming.

\subsubsection{Natural Vegetation}

In contrast to the exploitation which occurred in the past, the world's forest resources deserve special function for tourism development. In most developed countries forests and woodlands are valued for recreation and

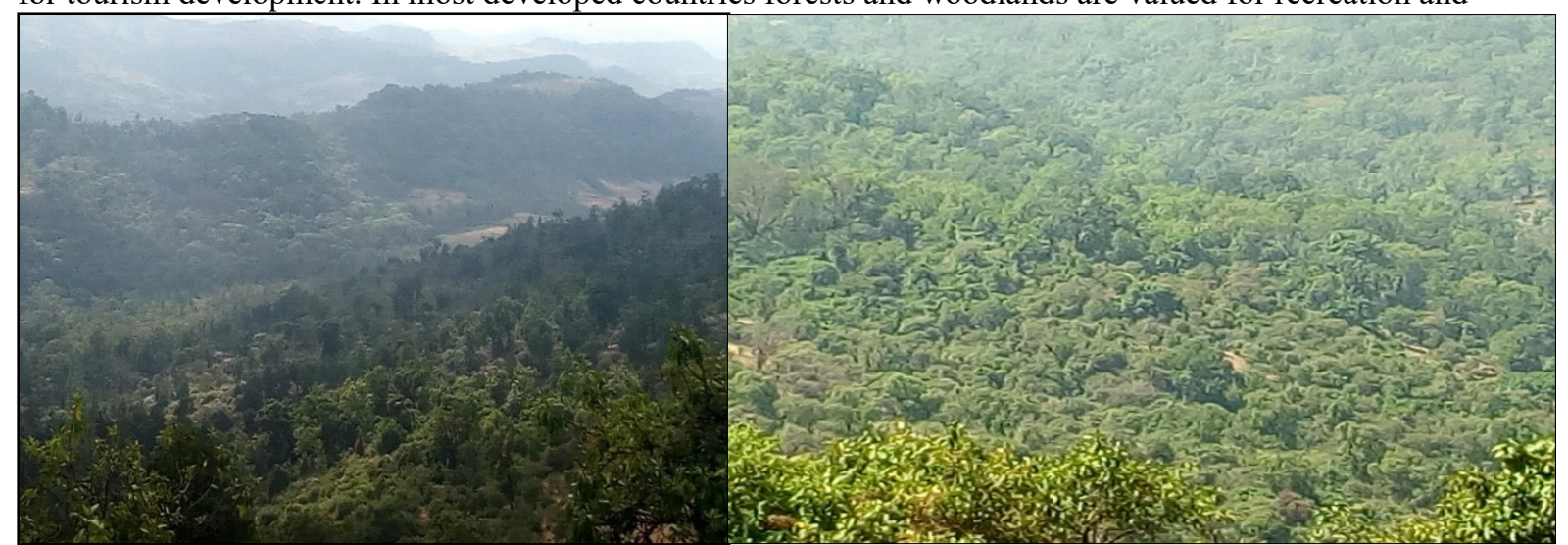

Figure 4.1: Photo of Kehitaste Forest; Source Author's own photographing, Feb. 2019

Wildlife protection,. Multiple uses are characteristic of such areas, and careful management is essential to protect the resource. CBET is one mechanism of protecting the resources as well as simultaneously benefiting local community (Stephen William, 2009). In this concern, the Kehitastse Forest is rich in flora biodiversity of which some of them are indigenous. The major vegetation types found at the study area consists of ever green small-leaved and broad-leaved trees, shrubs, climbers, ferns, and grass species. The forest also consists of some semi-green trees that fall their leaves during dry season such as Schefflera abyssinicca. Some of flora biodiversity species found in the forest include Accia lahai (Cheba), Allophylus abyssinicas (Embis), Apodytes dimidiate Dong), Arundinaria alpine (Kerkeha), Kniphofia foliosa (Ashengide), Barsama abyssinca (Azamira), Bruceaantid senterrica (Anfar/Ashiquar), Clausena anistat (Limich), Clematis simensis (Azo hereg), Croton macrostachyus (Bisana), Dombeya torrid (Wulkifa), Dovyalis abyssinica (Koshim / Aguam), Drace aderi (Mota), Ekebergia capensis (Entatay/Lol), Acanthus sennii (Kosheshila), Embelia schimperi (Enkoko), Juniperes procera (Yabasha thid), Eryythrina brucei (Korch), Maesalan ceolata (Quilabo), Mystenussene galensis (Quoba), Olea sp. (Weira), Phytolacca dodecandra (Endod), Pruna fricanus (Koma), Rosa abyssinica (Kega), Rubusa petolas (Enjori), Schefflera abyssinicca (Getum), Urearahy pselodendron (Lankusho), Vernonia amygdalina (Grawa).

However, some flora species have not given common name names. Such flora species with local names include sasa/hantsini, bahusti, shagimbi, thatsi, ensat/emparpari, Kulkuli, Girawa/huhitsi, awidi, galmatsi, zegristi, hohasfuchi, sharanga/niwri, entat/antwi, merkidi, abbra/ababri, tiksi/tihitihitsi, kenebari, dinkifi, empahipahi, takatiya, simbitibit/simbitibti, awiri ahara, gashini ahara, enkiki ahara, and etc.

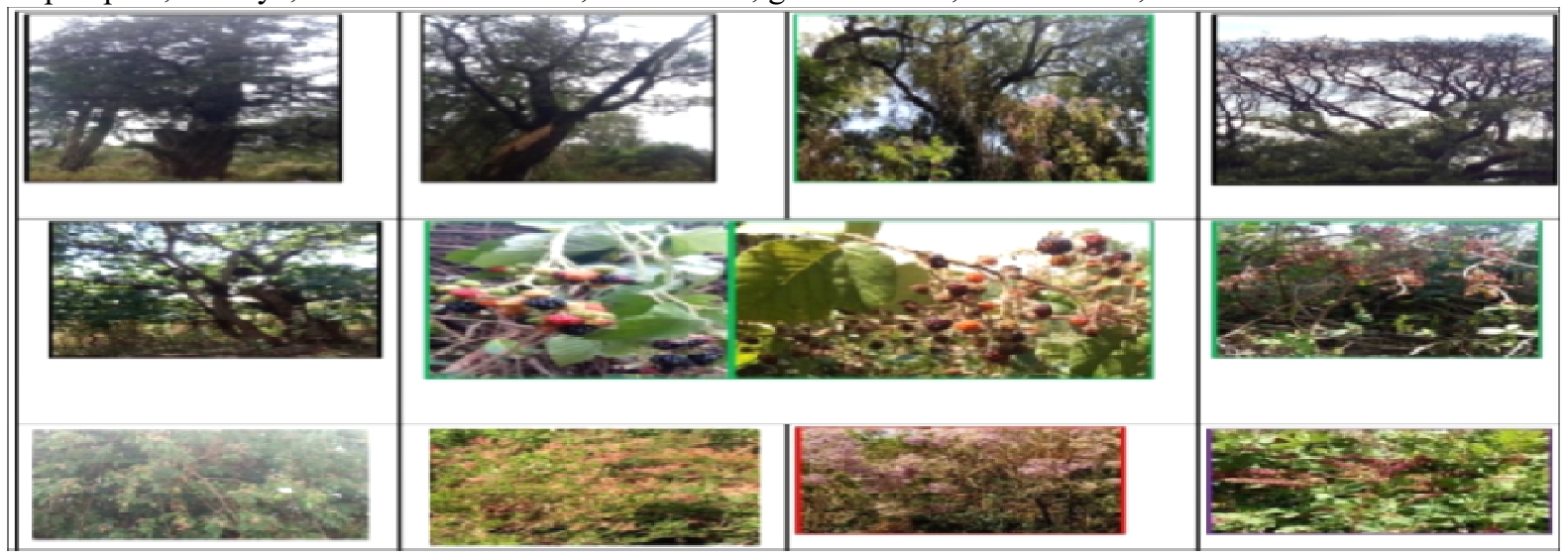

Figure 4.2: some of attractive potential plant species for ecotourism (Juniperus procera, Olive, Prunusafaricanus, Schefflerabyssinica, Ficussur, Strawberry, Embeliaschimpri, Rosaabyssinica, Emboch, Kokesfuchi, Endod)

Source: Author"s photograph, February 2019

The forest is also rich in flowering, and medicinal plants for human and domestic animals like embelias chimpri (enkoko) and there are also edible plants such as Rosa abyssinica and strawberry as depicted in fig 4.3. Abundance of flora biodiversity such as broad-leaved and small-leaved trees, shrubs, ferns, and grass species and natural bamboo that found at river banks, and mostly different climber types make the forest to be jungle 
and favorable habitat for wild animals'. These all together put the forest rich in green and wild life tourism which is sustainable development idea. As result, local communities can develop CBET with green and wild life tourism as niche product supply including gungle tourism at dense forest zones.

4.1.1.2 Fauna: The wildlife tourism is becoming an increasingly important component of tourism industry in the world. In recent years, increased demand for closer interaction with wildlife in their natural habitats is encouraging sustainable growth of wildlife tourism (Green and Higginbottom 2001). Animal biodiversity is a driving force for ecotourism development. Some of typical mammals found at the study area

include Abicauda/ Mongoose, Abyssinian colobus, Common duiker, Papio Anubis/Anibuis baboon, Colobus guereza/Colobu baboon, Common Baboon/ Monkey, Conis aureus/ Golden/Common Jackel, Crocuta crocuta/Spoted hyena, Felisa serva/Serval, Panthem pardus/ leopard, Potamochoerus larvatus/ Bush pig, Pygery thythrus/Ape, Sylvicapra grimma/ common/Bush duiker, Trafelaphus/Bush back, Wild cat, Hare, Baradili. In addition to mammals, the forest is also home to many types of bird species mainly,

Aquila rapax/Tawny eagle, Columba gulnea/Speckedpigon, Corvuscrassirostriss/ Thick billed raven, Occuipitalis/ Vulture, Bucovas Abyssinicus/ abyssinian ground hombill, Buzzaud/ gadie, Spersa/ Black duck, Sand grouses/ Dirchit, Streptopeli capicola/ Ring necked dove, Spor fowl, Sandy grouse, Hauk, Buzzaaud, Hammer kop.

The real world of wild life can be observed although it needs patience and long hours to get the chance to photograph them since some of mammals run and escape when see human, some others also jump from top of high ceiling trees to trees. Concerning to Bird species, they are abundantly observed with different attractive colors and their characteristics. One can observe them when flying from place to place, dancing, hunting, collecting food, eating, feeding their offspring, shouting and singing cheerfully, making living house and doing other different activities.

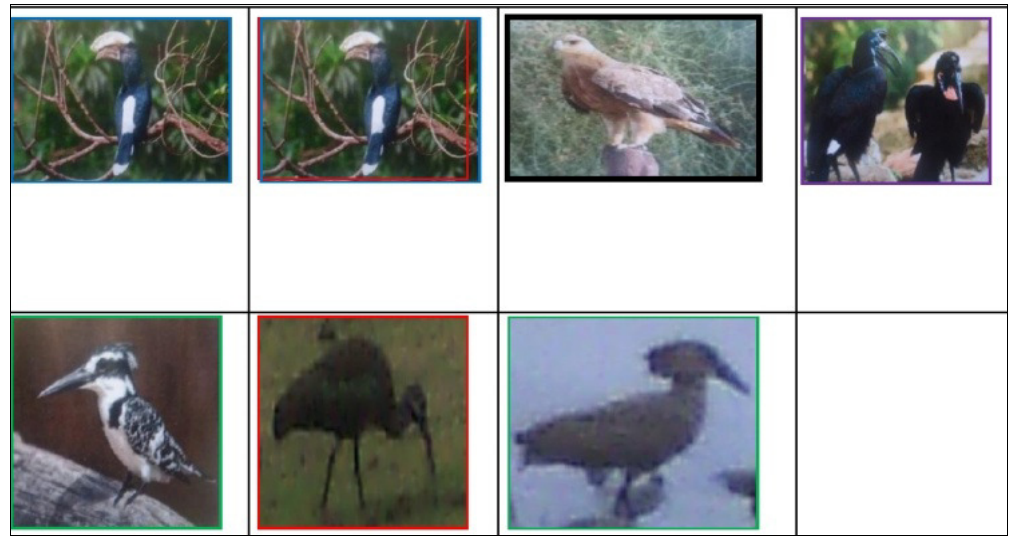

Figure 4.3: Some of bird species (Horn bill, Abyssinian rapax, Abyssinian ground horn bill, wood picker, water bill, Hammer kop; Source: Author's Field observation, Feb. 2019

As the study reveals, the existence of rich animal biodiversity at protected areas is great opportunity to develop CBET for increasing demand of tourists for niche tourism such as wildlife tourism, bird watching tourism, photographing tourism and controlled hunting tourism. 


\subsubsection{Landscapes, Water Bodies and Climate}

These Physical features of land and sea are unevenly distributed throughout the world which has important implications for climate variation, population distribution, economic development, and communication. The land surface of the earth is composed of a variety of landforms which are potential resources for tourism development. Mountain ranges are found in every continent and attract many tourists interested in sightseeing. This is due to the variety of scenic features, including spectacular mountain peaks, glaciers, cirques, lakes and waterfalls, as well as the crisp clear air which encourages a range of activity and adventure holidays. Most of these involve limited numbers of visitors and are the concern of „niche" tour operators dealing directly with their customers. (Stephen William, 2009).

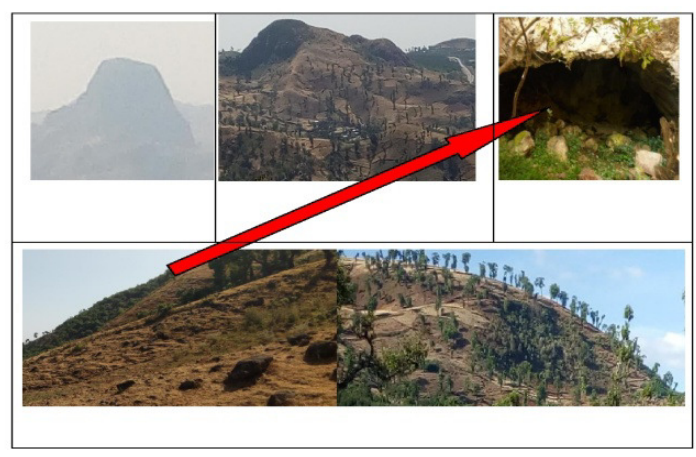

Figure 4.4: Some of impresive land scapes ( Fudi Mountain, Brasti LandScap, Nana Cave and Didma High Plateau respectively); Source: Field observation, Feb. 2019

Some of the potential attractions in the stud area are scenic views of its landscapes. Terrain stretches, mountainous topography, hills, plateaus, gorges and cliffs mainly Fudi Mountain, Biratsi landscape, Nana cave and Didma high plateau are distinctive features of the area. The forest largely shares the boundary of Didma high plateau which stretches gently towards the forest from eastern direction. This plateau is suitable for trekking. When one climbs the top of the plateau, panoramic view of distant places with different attractive views of landscapes can be seen although it is difficult to catch up the end of the view. It is also very interesting to see sun rising and sunset on the top of the plateau. The forest and environs is as well rich in small rivers and streams that flow towards western part of the forest and finally join the main tributary rivers of the Blue Nile River. Hence; the existence of the forest has great value for existence of such water bodies that are very important for existence of the biodiversity and highly exploited for irrigation at most of its lower courses.

The other interesting resource that should be remembered for tourism development at study area is climate with moderate agro ecological zone: $18^{\circ} \mathrm{c}$ average temperature and $2000 \mathrm{~mm}$ average annual rain fall that gains from mid may to end of September. According to Brai G., Boniface and Chris C. (2005), climate is considered as encouraging as well as limiting resource for development of tourist flow to destination. On a world scale, the importance of climate is shown in the broad pattern of travel decision. Climate largely determines the length of the tourist stay. Destination's development and operating costs; sales of beverages and leisure equipment are as well affected by weather changes, while the providers of tourist services have to cope with seasonal variations in demand. In most destinations, the problem of seasonality seriously affects profitability and employment in the tourism industry (Brai G., Boniface and Chris C., 2005).

\subsubsection{Cultural Attractions}

According to Awi zone Culture and Tourism Office representative key interview respondent, "Awi people are notably rich in attractive cultural values; cultural events and festivals, traditional social activities and conflict resolution. The zone is known in long aged churches and monasteries, burial places, holy waters, traditional local customs and living culture such as housing and living style of local villagers, cultural foods and drinks, dressing and hair styles, handcrafts housing and household materials as well as traditional agricultural activities. Awi people are also well known in horse riding with giant association which is called 'Yesebet bet Agew yealem feresegnoch mahiber/ seven houses Agew horse riders' association'. There are more than 48,000 members of this association. It has historic, social and religious values. Historically, the association was started after liberation of Ethiopia from Italian occupation in 1941. During Italian occupation; Awi patriots have played a lion's share as other parts of Ethiopians to defeat Italians. After return from battle field, Awi patriots established horse riders association to remember the role of horse at battle field to defeat Italians. It is colorfully celebrated per year on January 23 E.C. Cultural foods and drinks are carefully prepared and invited to invited guests during celebration. Socially, the association plays a vital role in creating a great alliance between communities. They use the association as a tool for conflict resolution, funeral, religious festivals, wedding ceremonies and economic development. There is an effort to register such association in UNESCO as world heritage site. Tourists can discover Awi culture at small towns on Saturday market when communities are selling and buying locally produced agricultural and handcraft products" he said.Local communities can develop their unique cultural 
resources into CBET and attract domestic and international tourists to get benefit in different aspects- they can get economic benefit from supply of cultural tourism products and services; they can upgrade social activity; ultimately, they can conserve their original culture.

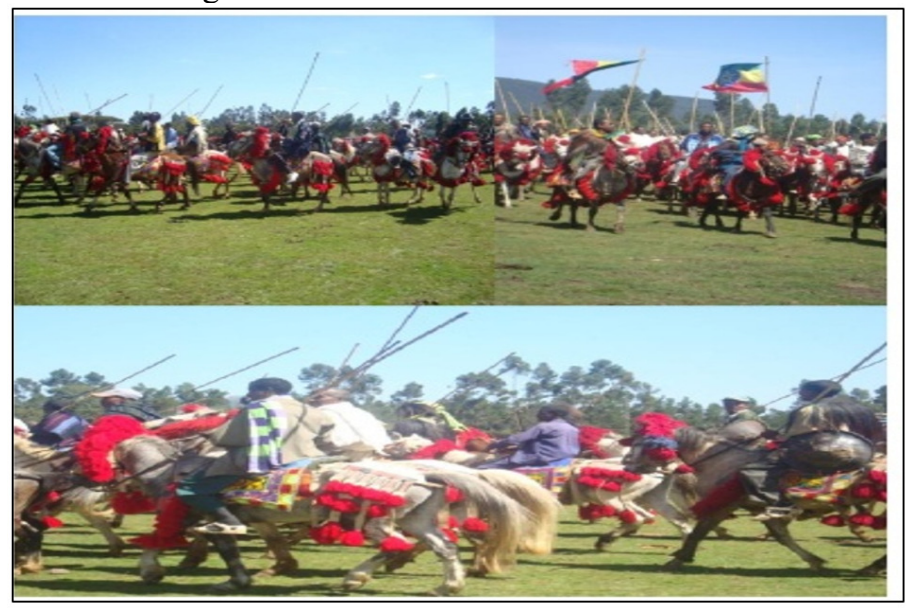

Figure 4.5: Horse Riders celebrating the Festival, Source: Field observation, Feb. 2019

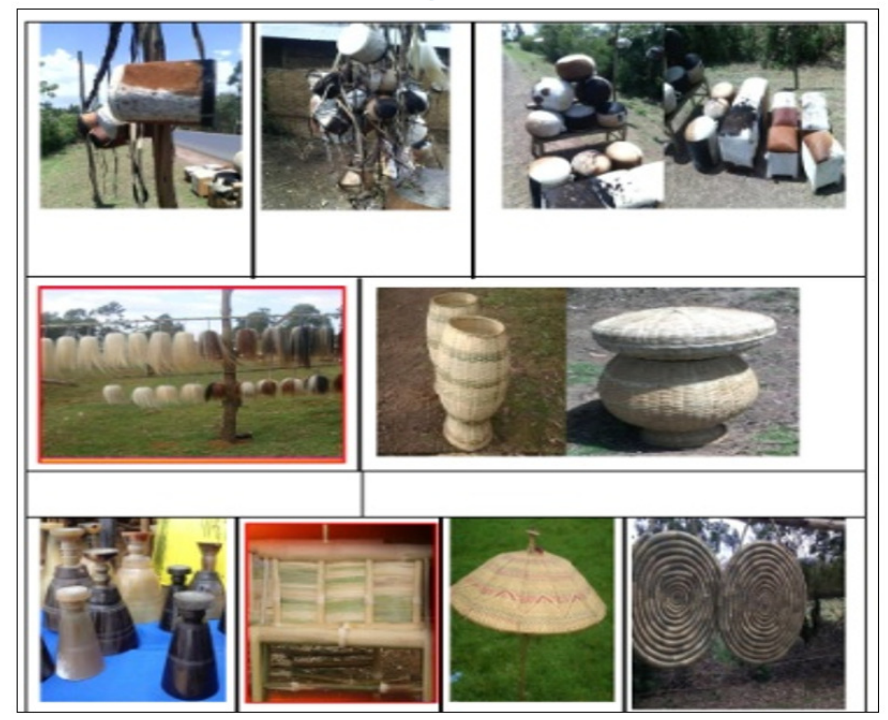

Figure 4.6: Handcrafts; Source: Field observation, Feb. 2019

\subsection{Communities' Awareness and Engagement towards Community Based Ecotourism Development} Local traditions, availabilities and quality of amenities, awareness and attitudes towards tourists are key factors in the success of ecotourism sectors business (Mathieson and wall, 1982). Host communities ${ }^{\text {ee }}$ support and participation in the planning and provision of ecotourism is fundamental to realize its benefits (Rosss and wall, 1999). 
Table 4.1: Awareness of local communitiese and their engagement to involve in Community based ecotourism activities

\begin{tabular}{|l|l|l|l|l|l|l|l|l|l|}
\hline \multicolumn{7}{c|}{ Yes } \\
\multicolumn{2}{|c|}{ Questions } & Countt & $\%$ & Count & $\%$ & \multicolumn{2}{c|}{ Count } & $\%$ & \\
\hline
\end{tabular}

Source: field survey, February 2019

As table 4.1 reveals most of sample household respondents have awareness, positive attitude and engagement to involve in CBET development at the study area. 95\% of them responded as they know about the meaning of tourism, and $92 \%$ of them also responded as they know the importance of flora, fauna and local culture as tourism attraction. However, this does not mean that they recognize perfectly, it may be from their understanding of tourist activities since all of respondents have said that they have seen when tourists have been traveling to their local area and photographing. $86 \%$ of respondents replayed as they have awareness about the purpose of tourists travel to their local areas. Most of them responded as government officials traveling to their local areas and photographing and/ or video graphing for government report purpose and to register heritage resources of the church, to visit the situation of infrastructures at local areas, to share experience of locally expanded Acacia decurrence agro forestry plantation that are traveling from other woredas and zones of the Amhara region. In addition, Sample household respondents replied that government officials also occasionally survey about the communities way of life, family background and economic activities. Besides these, sample household respondents added as tourists are traveling to watch wild animals, mountains, cave, terracing, irrigation, horse riders association and religious festivals and celebration. They also travel for funeral and to visit relatives. Many people also travel from remote area to Zik Abo church which is located inside the forest for holly water (to get relief from illness).

Furthermore, sample household respondents answered as many students also travel from neighboring schools to visit Cave Nana. According to local communities' oral tradition, cave Nana is historical cave and prosperous in resources. Aza Nana who was the powerful ruler at local area during Gonderine period (1632-1855) had been using the cave to protect from enemies for long period of times. Local communities believe that the cave is rich in gold, Maria Teresa silver and other precious goods and historical household materials of King Aza Nana. According to them, unless the forest is owned and managed by community, they are doubtful as the forest may be owned either by private organization or NGO that may not equally benefit them. Due to this reason, they have awareness, positive attitude and engagement to involve and develop CBET at the study area. They added that, they have participated in different conferences and taken awareness creation training as one of current issues. The training included about importance of tourism, conservation of natural and cultural resources, hospitality and respecting of travelers, but this does not mean that they are aware and know everything in detail. Awi zone Culture and Tourism Bureau said,

"Although, local communities are engaged to participate in CBET development, they seek short term benefit rather than long term. They need per day payment during training, but Culture and Tourism Bureau do not have sufficient budget to pay for all of communities during awareness creation training. In addition to this, they expect immediate benefit from tourism activities."

According to Duffy (2006) however, establishment and development of CBET is very difficult to implement and passes many challenges in spite of the existence of possible opportunities. It is complex and challenging task; it is hard to immediately be successful and profitable in comparison with other projects; it 
needs a long term effort to develop new situation, to build capacity and follow up, monitor and evaluate activities, marketing as well as to ensure that the CBET moves forward.

\subsubsection{Areas of communities' interest to involve and benefit from CBET is development}

one of the goals of CBET is promoting new economic benefit of local communalities that are economically weak through employment in tourism enterprises; supply of goods and services to tourism enterprises by the poor, direct sales of goods and services to visitors by the poor such as local products and cultivated medicinal plants there by creating entrepreneurial skill (Lindberg, 2001).To realize CBET development, it requires identifying interest of local communities' involvement in what activities they engage to involve as shown in table 4.10 below.

Table 4.2: Areas of communities' interest to involve and benefit from CBET is development

\begin{tabular}{|c|c|c|c|c|c|c|c|}
\hline \multirow[t]{3}{*}{ S.NO } & \multirow{3}{*}{$\begin{array}{l}\text { Areas of communities' } \\
\text { interest to involve and } \\
\text { benefit from CBET is } \\
\text { development }\end{array}$} & \multicolumn{6}{|c|}{ Frequency o Response } \\
\hline & & Yes & & No & & Total & \\
\hline & & Count & $\%$ & Count & $\%$ & Count & $\%$ \\
\hline 1 & Provision of handcrafts & 21 & 23 & 70 & 77 & 91 & 100 \\
\hline 2 & Horse rental & 25 & 27 & 66 & 73 & 91 & 100 \\
\hline 3 & Horse riding & 24 & 26 & 67 & 74 & 91 & 100 \\
\hline 4 & $\begin{array}{l}\text { Cultural showing and } \\
\text { story telling }\end{array}$ & 6 & 7 & 85 & 93 & 91 & 100 \\
\hline 5 & $\begin{array}{l}\text { Traditional music and } \\
\text { dance }\end{array}$ & 3 & 3 & 88 & 97 & 91 & 100 \\
\hline 6 & Guiding & 4 & 4 & 87 & 96 & 91 & 100 \\
\hline 7 & $\begin{array}{l}\text { Provision of agricultural } \\
\text { products }\end{array}$ & 34 & 37 & 57 & 63 & 91 & 100 \\
\hline 8 & $\begin{array}{l}\text { Provision of other } \\
\text { commodities }\end{array}$ & 6 & 7 & 85 & 93 & 91 & 100 \\
\hline 9 & Bee keeping & 26 & 29 & 65 & 71 & 91 & 100 \\
\hline 10 & $\begin{array}{l}\text { Employment in } \\
\text { management }\end{array}$ & 2 & 2 & 89 & 98 & 91 & 100 \\
\hline 11 & $\begin{array}{l}\text { Employment in food and } \\
\text { beverage service }\end{array}$ & 2 & 2 & 89 & 98 & 91 & 100 \\
\hline 12 & Employment in cooking & 6 & 7 & 85 & 93 & 91 & 100 \\
\hline 13 & Employment in security & 3 & 3 & 88 & 97 & 91 & 100 \\
\hline 14 & Daily wage & 30 & 33 & 61 & 97 & 91 & 100 \\
\hline
\end{tabular}

Source: field survey, February 2019

The sample household respondents have shown their interest to involve in different tourism activities and services. Most of them are opting to involve and benefit in two or three activities. 37\%, 33\%, 27\%, 26\% and $23 \%$ are willing to engage in local agricultural supply, daily wage, bee keeping, horse rental, horse riding and provision of hand crafts respectively, but very few respondents are interested to be employed in management (2\%); similarly $2 \%$ are interested to be employed in food and beverage service, but $3 \%$ are engaged to be employed in security, and traditional music and dance, $4 \%$ in guiding and $7 \%$ in cooking. In the same way $7 \%$ are willing to engage in provision of different commodities.

Therefore, communities ${ }^{\text {ee }}$ engagement to involve in different activities can be considered as opportunities to develop CBET. Quality of products and services can be developed and improved through skill gap training. It cannot be the major problem since they are highly engaged and their engagement is based on their previous knowledge, skill and experience.

CBET is believed to have potential to contribute to local economic development through a widespread channel. It generates sustainable and independent source of funds for community development and Creates employment in tourism, Increases household income. At some ecotourism destinations, residents benefit from revenue sharing programs through either cash payments or, more commonly, funding for community projects such as wells or schools. Revenue derived through CBET includes entrance fees, admission fees, user fees, licenses and permits charges, royalties and sales revenue, concession fees and voluntary donations. CBET promotes new economic incentives, provides the local community with variety of jobs including, tour guides, mule suppliers, selling of local products, craft, food producers and cultivated medicinal plants thereby create some entrepreneurial skills; to ensure communal ownership and control, and that part of the profits flow into community development programs rather than into personal enrichment (Lindberg, 2001).

In achieving economic objectives of community based ecotourism efforts has to be made to benefit the local communities who are economically weak (UN, 2007). Regardless of tourism potential and communities engagement towards CBET development, currently, local communities of Kehitastse forest and environs are not 
getting economic benefit from tourism activities . They can develop and generate the income from entrance fee since the forest is potentially rich to develop wildlife tourism, bird watching, controlled hunting, hiking and trekking, rural/ agree tourism, sightseeing tour, cultural tourism and photographing types of tourism activities. If economically feasible community-based ecotourism is developed at protected area, it can enhance local communities job creation and diversification opportunity such as establishment and rent of community owned lodges, sales of locally produced hand crafts, foods, drinks and agricultural products; employment in food and beverage preparation and services, management, security, daily wage, tour guiding service, horse and/ or mule rental and riding, cultural showing, traditional music and dance, and other related services. Moreover, there might be a chance for Carbon sales and donors support.

Charles and Ritchie (2009) also looked economic impacts from direct, indirect and induced benefit point of view. The direct economic effects are those that occur at front line tourism related establishments like community lodges, restaurants, souvenir shops, etc. The subsequent effect as a result of the direct economic effects can be called as indirect income. For instance, when the tourists spend money in a community lodge, the lodge will spend some of the money it receives on food and beverage supplies and other business services and so on. The induced economic effects occur because of direct and indirect levels of economic impacts; income will occur to the residents of the local economy and this will generate further level of economic activity through multiplier effect. The economic benefit thus passes through out the tourism system. In achieving economic objectives of community based ecotourism efforts has to be made to benefit the local communities who are economically weak (Charles and Ritchie, 2009). Over all, the ultimate goal of economic benefit is to bring better standard of living which enhances job creation, better income, nutritional status, good hygiene, community pride and gender and age equality, building capacity for community management organizations (Tuffin, 2005). However, household income level for many of local communities of study area is difficult to survive since they are dependent on limited natural resource more likely subsistence agricultural activity while there is decreased productivity of land from time to time, high need of fertilizers, dissected and traditional agricultural activity and increase of family size without diversified source of income. According to IUCN (1999), this problem of poverty on local communities can be minimized through diversifying the source of income such as sustainable development of CBET (IUCN, 1999). Consequently, the development of CBET can bring better standard of living to local communities (Charles and Ritchie, 2009).

\subsection{Challenges of the Forest}

According to Honshu and Mintong (2009), CBET is sustainable tourism which is based on ecological principles and sustainable development strategy. Its main aim is to conserve resource, especially biodiversity, and maintain sustainable use of resources. Sherman and Dix (1991) added about environmental benefit of tourism as it ensures that resources used today are available to future generations. Thus it justifies environmental protection and improvement, but this principles and strategies are not properly applied at Kahitestsa forest due to Poor conservation strategy and dependency of local community's on natural resources although they have taken awareness creation training about environmental conservation. Local communities are exploiting the forest illegally for various purposes such as for grazing, fire wood, housing, charcoal, lumbering household materials and agricultural tools. These can bring adverse effect on sustainable development of the forest.

\section{Table 4.3: Communities Unsustainable Use of the Forest}

\begin{tabular}{|c|c|c|c|c|c|c|c|c|c|c|c|c|c|}
\hline \multirow[t]{3}{*}{$\begin{array}{l}\text { S. } \\
\text { No. }\end{array}$} & \multirow{3}{*}{$\begin{array}{l}\text { For what purpose } \\
\text { do communities use } \\
\text { the forest at } \\
\text { current time? }\end{array}$} & \multicolumn{6}{|c|}{ Frequency of Response } & \multirow{2}{*}{\multicolumn{2}{|c|}{ Iow }} & \multirow{2}{*}{\multicolumn{2}{|c|}{ Not at all }} & \multirow[b]{2}{*}{ Total } & \multirow[b]{3}{*}{$\%$} \\
\hline & & Very & & High & & Mediu & & & & & & & \\
\hline & & Count & $\%$ & Count & $\%$ & Count & $\%$ & Count & $\%$ & Count & $\%$ & Count & \\
\hline 1 & For fire wood & 0 & 0 & 0 & 0 & 3 & 3 & 88 & 97 & 0 & 0 & 91 & 100 \\
\hline 2 & For housing & 0 & 0 & 0 & 0 & 1 & 1 & 53 & 58 & 37 & 37 & 91 & 100 \\
\hline 3 & $\begin{array}{l}\text { For household } \\
\text { materials }\end{array}$ & 0 & 0 & 0 & 0 & 5 & 6 & 85 & 93 & 1 & 1 & 91 & 100 \\
\hline 4 & For agricultural tools & 0 & 0 & 0 & 0 & 59 & 65 & 29 & 32 & 3 & 3 & 91 & 100 \\
\hline 5 & For charcoal & 0 & 0 & 0 & 0 & 0 & 0 & 8 & 9 & 83 & 83 & 91 & 100 \\
\hline 6 & For grazing & 58 & 64 & 33 & 36 & 0 & 0 & 0 & 0 & 0 & 0 & 91 & 100 \\
\hline 7 & production & 2 & 2 & 14 & 15 & 60 & 66 & 15 & 17 & 0 & 0 & 91 & 100 \\
\hline 8 & For lumbering & 0 & 0 & 0 & 0 & 6 & 7 & 85 & 93 & 0 & 0 & 91 & 100 \\
\hline 9 & For medicine & 0 & 0 & 4 & 4 & 49 & 54 & 38 & 42 & 0 & 0 & 91 & 100 \\
\hline
\end{tabular}

Source: own field survey, February 2019

The major head ache of the forest is overgrazing. When sample household respondents were asked about this issue, $64 \%$ and $36 \%$ replayed as they use at very high and high intensity correspondingly, but nobody responded at medium, low and not at all levels. This implies that, raring of domestic animals in the forest is not 
restricted although it is stated in the Forest management, control, and using regulation of Amhara regional state proclamation No 002/ 1999. According to this proclamation article 5.1, state forest should be used for different purposes when permitted by authorized body of agricultural and rural development. This article clearly denoted that, the forest can be used for different purposes without harming natural regeneration potential of the forest. In such state, local communities can use the forest for domestic animals' food, medicine, bee keeping and collection of dry woods for fire wood.

Sample household respondents replayed that communities use the forest for fire wood at low rate $97 \%$ and $3 \%$ at medium rate. Similarly, the practice of local communities to use forest for household materials is $93 \%$ at low, $6 \%$ medium intensity and $1 \%$ not using at all. Likewise, $93 \%$ and $7 \%$ of respondents use the forest for

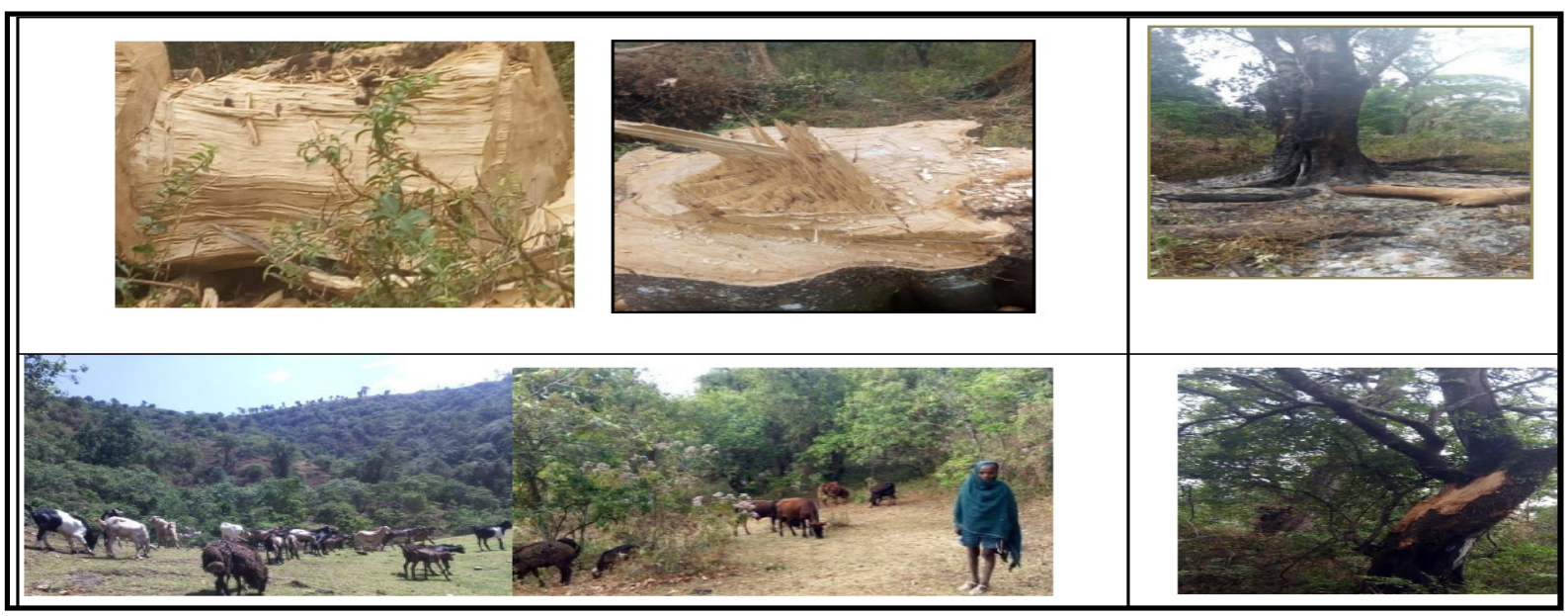

Fig 4.6: unsustainable use of the forest illegally; source: Field observation 2019

lumbering at low and medium rate respectively. They also use the forest for housing 58\% at low level and $1 \%$ at medium level, but $41 \%$ do not use it at all. Sample household respondents also replayed that $65 \%$ and $32 \%$ of them use the forest for agricultural tools at medium and low intensity respectively. The remaining 3\% do not use it at all. Regarding to the use of local communities for charcoal production, only $9 \%$ use it at low level. The remaining $91 \%$ do not use at all. Local communities also use the forest for honey production and medical purpose which have not significant adverse effect to the forest sustainability.

The interference of communities to use the forest for housing, household materials, agricultural tools, and charcoal production seems insignificant problem; but when all these illegal practices are summed up together, they contribute adverse effect to forest sustainability through time. Besides these, local communities also use the olive trees for smoking bee heaves and jars since it has pleasant smell. According to sample household respondents, the reason for poor conservations include (1) Communities dependency on natural resources and illegal use of the forest, (2) forest securities are not strictly following up the activity (3) experts from the natural resource and forest bureaus do not supervise and follow up the activities of forest securitiesSimilarly, key informant interview respondents from Banja Shekudad, Fagita Lakoma and Ankasha Gogusa woredas and Awi zone natural resource and forest bureaus added that the main challenge for conservation of the forest are lack of sufficient forest experts in their organizations for supervision, follow up and office works; lack of forest securities and insufficient payment of salary; lack of sufficient budget and local communities illegal use of forest for different purposes. Forest securities added that, there is no strict supervision and follow up due to lack of sufficient security, low monthly salary of security and low support from natural resource and forest bureau.

Measures are taken when local communities' violate the regulation of the forest conservation, According to sample house held respondents, the following measures are taken. First evidence is required from forest securities and local communities, i.e. security force or local communities present those people who use the forest illegally for different purposes to community leaders or elders and/ or concerned government body. Depending on the level of violating the regulation, they are given the advice and warning, as well as punishment through money and/ or prison. Currently, hunting and cutting green trees is serious regulation and strictly forbidden by law. If communities do such activities, they will be punished up to 2 years prison or 10, 000. 00 birr, especially when one is repeatedly violating the rule. Key informant interview respondents of forest securities from selected sample sites as well as, Banja, Fagita Lakoma and Ankasha Gogusa woredas and Awi zone natural resource and forest bureaus stated similar idea. Due to this reason rule violation is decreasing from time to time, but since securities follow up is poor still there is illegally use of the forest. 


\section{Conclusion and recommendation}

The finding indicates that Kahitestsa forest is potential site to development CBET: existence of abundant natural and cultural potential tourism resources, favorable habitat for wild life, existence of proper demarcation, local communities positive attitude towards tourism and tourists, Accessibility of forest to highway of historical route of Ethiopia via Injibara town and the availability of accommodation at this town, accessibility of Cooperatives and micro finance institutions, existence of environmental and tourism developmental policy that favors community involvement to be beneficiary.

In spite of these opportunities, the study also indicates that there are a number of challenges that can deter the development of CBET at the study area. Majority of local communities are dependent on natural resources and agricultural activity. Due to poor conservation strategy, local communities are exploiting the forest illegally for various purposes such as firewood, grazing, charcoal, lumbering, housing, and household materials which are determinant factors for sustainable development of forest. All of these human factors can harm natural resources including biodiversity without considering sustainability.

Therefore, to use the potential tourism resources at maximum point and to minimize challenges to bring sustainable local development through CBET, the following points are recommended:

$>$ Conservation strategy of the forest should be strengthened to protect illegal use of resources. Thus, Conservation awareness and local communities' ownership of the resources should be implemented; relying on firewood for cooking and lighting should be developed in to use of renewable source of energy such as bio gas, solar energy and other technology options.

$>$ Bureau of Culture and Tourism of Fagita Lakoma, Banja shekudad and Ankasha Gogusa Woredas as well as Awi zone should play significant role in supporting CBET development initiatives and Provide training to culture and tourism staffs as well as host communities on basic skills of communication, hospitality, customer service and care, CBET product development, business planning, marketing and promotion of the resources. Local communities should be trained and certified on the tour guiding, food and beverage preparation and service, handcraft production, organization of cultural events and other essential services that can diversify economic participation of local communities and bring sustainable development of CBET.

$>$ Environmentally sound, culturally friendly and economically feasible CBET should be developed. Thus, environmentally friendly lodges that reflect the local culture of the area should be constructed from local materials. Since the forest has rich potential tourism resources, wildlife tourism, bird watching, controlled hunting of colobus baboon and olive/ common monkey hiking, trekking, agree tourism, geo and sightseeing tourism, cultural tour and photographing form of tourism should be developed.

$>$ Horse and mule transportation service should be supplied to solve transportation problem and to benefit local communities. Strong engagement and cooperative relationship among key stakeholders of tourism industry should be built to involve in CBET businesses activities. Obtaining financial resources to operate the CBET business for the first few years is among the most important barrier to doing business due to difficulties in obtaining loans from financial institutions, thus there should be a developed especial funding mechanisms/ frameworks for CBET businesses to avoid financial barriers.

\section{References}

Adem, G. (2008). Assessment of Ecotourism Potentials for Sustainable Natural resource development. Unpublished M.A thesis paper. Tourism and development, Addis Ababa

BoFED (2012) Development indicators of the Amhara National Regional State of the year 2011/12. Bahir Dar, Ethiopia

Brai G. Boniface and Chris C. (2005), Worldwide destinations: The geography of travel and tourism (4th ed.). Oxford, UK. Elsevier Science Ltd.

Cater E. and Lowman, G. (1994). Ecotourism: A Sustainable Option? UK. John Wiley and Sons Inc.

Charles, R., and Ritchie, J.R. (2009). Tourism Principles, Practices and Philosophies. New Jersey. John Wiley and Sons, Inc.

Cole, S. (2006). Cultural tourism, community participation and empowerment: Great Britain Channel View Publications, pp. 89-103

Cresswell, C. and MacLaren, F. (2000). Tourism and National Parks in Emerging Tourism Countries: Issues and Implications. London. John Wiley and Sons Ltd., pp 283-389

Denman, R. (2001). Guidelines for Community Based Ecotourism Development. Washington: Department for International Development (DFID)

Duffy, R. (2006). A trip too far: ecotourism, politics, and exploitation. London. Earth scan. (2006). Global Environmental Governance and the Politics of Ecotourism in Madagascar. Journal of Ecotourism, 5 (1and2), 128-144

Ethiopian Tourism Commission (ETC). (1995). Regional tourism development plan for North, East and West 
Ethiopia (Unpublished material) Ecotourism Association of Ethiopia (EAE). Promoting sustainable tourism in Ethiopia. Retrieved from www.ecotorismethiopia.org . on 22/5/09

EWCA (2015). Ecotourism potentials of Ethiopia Booklet

Green, R. and K. Higginbottom (2001). The Negative Effects of Wildlife Tourism on Wildlife: With a Focus on Non- Consumptive Free-Ranging Terrestrial Wildlife Tourism. Brisbane. CRC for Sustainable Tourism

Henze, B.P. (2007). Ecotourism in Ethiopia: Opportunities and ideas. Conference of IDR/AAU. Retrieved from www.irrrob.org/ecotourism-in- ethiopia.html.on28/6/09

Hong, E. (1985). See the Third World while it lasts: the Social and Environmental Impact of Tourism with Special Reference to Malaysia, Penang. Consumers ${ }^{\text {ee }}$ Association ofPenang

Hongshu, W. and Min, T. (2009). Research on Community Participation and Environmental Management of Ecotourism: North East Forestry University of China. International Journal of Business and Management

IUCN (1999). Parks for Biodiversity: Policy Guidance based on experience in ACP Countries. For the European Commission by IUCN, Gland, Switzerland and Cambridge, UK

(2002) Sustainable Tourism in Protected Areas: Guidelines for Planning and Management. For United Nations Environment Programme and World Tourism Organization: by IUCN, Gland, Switzerland and Cambridge, UK.

Kelly, E. (2009). An Assessment of the Potential for Developing Ecotourism in the San Francisco, Menendez Sector of El Imposible National Park. El Salvador. Alaska University press

Lindberg, K. (2001). Economic Impacts of Ecotourism. In D.B. Weaver (ed.) the Encyclopedia of Ecotourism 363-377. Wallingford, CABI

Lindberg, K., Enriquez, J. and Sproule, K. (1996). Ecotourism questioned: case studies from Belize. Annals of Tourism Research. 23, 543-6

Mathieson, A. and Wall, G. (1982). Tourism: Economic, Physical, and Social Impacts. Journal of Travel Research, 151 (22), 5

McNealy, J-A. (1992). Parks for Life, Paper Prepared for 4th World Congress on National Parks and Protected Areas

Miller, L. (2004). Evaluating the Design and Management of Community Based Ecotourism

Projects in Guatemala. Unpublished MSc Thesis, B.S. Montana University

Murphy (1985). Tourism: The Community Approach, London. Rutledge

Norris, R. (1992). Can Ecotourism Save Natural Areas? National parks, Pp 31-40 Schyvens, R. (1999). Ecotourism and Empowerment of Local Communities. Tourism Management

Ross, S. and Wall, G. (1999). Ecotourism: Towards Congruence between Theory and Practice. Tourism Management, 20 (1), 123-132

SDPASE, (2008). Protected Areas of Ethiopia: Information Bulletin

Sherman, P. and Dixon, J. (1991). The economics of nature tourism: determining if it pays. London. Rutledge

Sofield, H. B. T. (2003). Empowerment for sustainable tourism development. Oxford UK, Elsevier Science Ltd.

Sproule, K. W. (1996). Community-based ecotourism development: Identifying Partners in the process, The Ecotourism Equation and Measuring the Impacts, 233-50

Stephen, W. (2009). Tourism geography: new synthesis (2nd ed.) USA and Canada. Rout ledge

Tesfaye, H. (1996). Utilization of wildlife in Ethiopia. Journal of EWNHS 17,3-9

Tuffin, Bill. (2005). Community-Based Tourism in the Lao PDR: An Overview in Improving Livelihoods in the Uplands of the Lao PDR. NAFRI. NAFES NUOL

UN, (2007). Study on the role of tourism in socio-economic development. New York. Economic and social commission for Asia and the pacific University

UNWTO, (1997). Word Tourism Leaderse Meeting on the Social Impacts of Tourism: Paper Prepared for, World Tourism Leaders. Retrieved from http:/www.unwto.org/ 2016

Viva Ethiopia Tour (2014). Natural Tourism Attractions of Ethiopia: retrieved from http:/www.vivaethio.tour.org/2016

Weaver, D. and Lawton, L. (2007). Twenty years on: The State of Contemporary Ecotourism Research. Tourism Management, 28, 1168-1179

World Tourism Organization (2001). Guidelines for community based ecotourism development Madrid WWF International. available at http://www.wwf.org.uk/ filelibrary/ pdf/ community_based_ecotourism.pdf 